DOI: http://doi.org/10.31617/k.knute.2019-04-12.17

Расулова А.М., к. е. н., дои. Google Scholar https://scholar.google.com.ua/citations? user $=V t n 6 a 68 A A A A J \& h l=u k$ Компанець К.А., к. е. н. Google Scholar https://scholar.google.com/citations?hl=ru\&view Київський національний торговельно-економічний університет, м. Київ, Україна

\title{
ДЕВЕЛОПМЕНТ ГОТЕЛЬНОЇ НЕРУХОМОСТІ
}

Процес розвитку готельних проектів вимагає чіткого бачення, стратегічного планування та професійного підходу, оскільки діючий економічний ландшафт змушує девелоперів ретельно виважувати кожне рішення щодо ключових позицій функціонування готелю.

Девелопмент готельної нерухомості досить ризикований, але дохідний бізнес. Девелопери не тільки зводять будівлю, але i займаються пошуком та оформленням земельної ділянки, визначають маркетингову політику об'єкта, розробляють будівельний план i дизайн-проект, отримують всю необхідну документацію, фінансують угоди, розробляють концепцію та формат готелю, системи дистрибуції послуг та залучення гостей, контролюють і керують усім процесом від початку до кінця реалізації проекту.

За підсумками звіту Lodging Econometrics за 2018 рік, загальний обсяг будівництва на різних стадіях в Свропі сягнув до 1569 готелів (243 947 номерів), досягнувши 19\% зростання порівняно з минулим роком - найвищого показника за весь період моніторингу [1].

Динаміка розвитку ринку готельного девелопменту країн Європи 3a 2018-2020 pp.

\begin{tabular}{|l|c|c|}
\hline \multicolumn{1}{|c|}{ Періоди та етап реалізації проекту } & Готелів & Номерів \\
\hline 2018 р.: відкрито & 386 & 53236 \\
\hline на стадії будівництва & 784 & 124674 \\
\hline планують почати будівництво у найближчі 12 місяців & 434 & 68128 \\
\hline на ранній стадії планування & 351 & 51145 \\
\hline 2019 р.: прогноз & 382 & 53252 \\
\hline 2020 р.: прогноз & 386 & 59861 \\
\hline
\end{tabular}


Провідними країнами Свропи у будівництві готелів є Німеччина, Великобританія, Франція, Польща і Португалія.

Ринок готельної нерухомості України завжди був одним 3 найскладніших для девелоперів: відсутність фінансової стабільності і адекватного правового регулювання, а також стабільного платоспроможного попиту, стримували його планомірний розвиток.

Ефективність готельних девелоперських проектів залежить від низки чинників на різних рівнях, етапах їх планування та реалізації:

1) На рівні місцевих органів влади - стимулювання будівельної галузі, спрощення вимог і процедур відведення земельної ділянки, узгодження проектної документації, надання дозволів, введення «податкових канікул» та інших заходів.

2) На етапі розроблення проектів:

a) вибір місця розташування на $50 \%$ визначає успіх проекту: локація, доступність до комунальної інфраструктури тощо.

б) залучення відомого готельного бренду на умовах франчайзингу, контрактного управління, концесії та ін. [2].

в) пошук стабільного кредитора (групи кредиторів), які охочіше фінансують проекти, узгоджені 3 надійним брендом зі своєю успішною готельною історією.

г) будівництво багатофункціонального комплексу з готельною складовою, замість готельного комплексу, що дозволяє скоротити терміни окупності проекту у цілому;

д) можливий перегляд «зірковості» готельного проекту (наприклад, будівництво готелю $4 *$ замість $5 *$ ).

е) придбання незавершених готельних проектів і об'єктів на вигідних умовах [3].

Готельний девелопмент - це унікальне комбінування підприємницької діяльності та мистецтва ведення бізнесу, оскільки охоплює спектр усіх складових успіху та розвитку готелю через використання ITтехнологій, планування фінансових показників, бенчмаркінг, стандартизацію послуг, систему менеджменту, маркетингову стратегію, якість послуг, дизайн інтер'єру та екстер'єру готелю, навчання працівників та розширення можливостей, а головне - рівень задоволення споживачів.

\section{Список бібліографічних посилань}

1. Jena Tesse Fox Hotel development in Europe hits record high. Режим доступу : https://www.hotelmanagement.net/development/hotel-develop ment-europe-hits-record-high. 
2. The Stages of Hotel Development, Part I - Defining the Action Plan. Режим доступу : https://www.hotelmanagement.net/sponsored/stageshotel-development-part-i-defining-action-plan.

3. Готельна нерухомість України: СВРО-2012 в допомогу. Режим доступу : https://www.dom2000.com/uk/articles/gotelna-neruhomist-ukrayiniyevro-v-dopomogu. 